\title{
THE PUNCTUATION OF HEBREWS 10:2 AND ITS SIGNIFICANCE FOR THE DATE OF HEBREWS
}

\author{
Philip Church \\ (pchurch@laidlaw.ac.nz)
}

\begin{abstract}
Summary
The significance of Hebrews 10:2 for the date of the letter has been the subject of debate, with some scholars finding it decisive for a pre-70 CE date and others denying it any importance, proposing (rightly) that the writer is arguing theoretically about sacrificial activity extending since the time of Aaron. The 2017 publication of the Tyndale House Greek New Testament brings the debate into sharp focus with Hebrews 10:2a punctuated as a statement ('If the sacrifices were effective, they would not have ceased to be offered') rather than a question ('If the sacrifices were effective, would they not have ceased to be offered?'). Reading the clause as a statement implies that the temple has fallen and sacrifices have ceased, leading to the conclusion that Hebrews postdates this event. An examination of the manuscript evidence, the history of interpretation, the syntax, and the context shows that the clause should be read as a rhetorical question expecting a positive answer from the readers: 'Yes, the sacrifices would have ceased if they were effective.' Even if the writer were arguing theoretically, this would be a difficult answer had the temple been destroyed. This makes a pre-70 date more likely than a post70 date.
\end{abstract}

\section{Introduction}

Hebrews 10:2 reads in the NRSV 'Otherwise, would ... [the sacrifices] not have ceased being offered, since the worshippers, cleansed once for all, would no longer have any consciousness of sin?' While this is clear enough, debate has swirled around its relevance for the date of Hebrews. In my 2017 monograph I wrote 
Hebrews 10:1-4 is a single sentence concluding with the declaration that animal sacrifices cannot remove sins. Verse 2 claims that the same sacrifices, continually offered year after year would have ceased being offered if they could make the worshippers perfect, and since they have not ceased, the people are still conscious of sin. I have deliberately paraphrased the sentence in this way, supplying the positive answer that

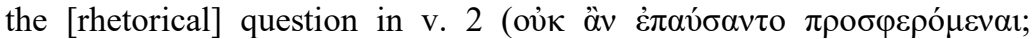
'would they not have ceased being offered?') demands ... In the context of Heb 10:1-4, the question about the cessation of sacrifice makes it almost certain that the temple was still in place with the sacrifices still being offered. ${ }^{1}$

\section{Kenneth Schenck disagrees:}

Philip Church ... cannot quite get beyond our hindsight to see that 10:1-4 would focus on over a millennium of sacrifices since their institution. Why did they not cease being offered for all time after Aaron's very first Day of Atonement? ${ }^{2}$

Schenck stands in an honourable tradition, citing an argument that goes back at least as far as Aquinas, who writes

because the worshippers once cleansed should have no conscience of sin any longer, so they would cease offering, because, as has been said, they offered the same sacrifices every year. Therefore, since they did not [ever] cease offering (Quia ergo non cessabant idem semper offerre), it is a sign that they were not cleansed. ${ }^{3}$

1 Philip Church, Hebrews and the Temple: Attitudes to the Temple in Second Temple Judaism and in Hebrews (NovTSup 171; Leiden: Brill, 2017): 14-15. Others who use this verse to date Hebrews prior to the destruction of the temple include B. F. Westcott, The Epistle to the Hebrews ( $3^{\text {rd }}$ edn; Grand Rapids: Eerdmans, 1909): xli; F. F. Bruce, The Epistle to the Hebrews (rev. edn, NICNT; Grand Rapids: Eerdmans, 1990): 236; David L. Allen, Hebrews (NAC 35; Nashville: Broadman \& Holman, 2010): 494-95; Peter T. O'Brien, The Letter to the Hebrews (Pillar New Testament Commentary; Grand Rapids: Eerdmans, 2010): 19; Philip Edgcumbe Hughes, A Commentary on the Epistle to the Hebrews (Grand Rapids: Eerdmans, 1977): 391; Ben Witherington III, Letters and Homilies for Jewish Christians: A Socio-Rhetorical Commentary on Hebrews, James and Jude (Downers Grove: IVP Academic, 2007): 277; Luke Timothy Johnson, Hebrews: A Commentary (NTL; Louisville: Westminster John Knox, 2006): 249-50; David A. DeSilva, Perseverance in Gratitude: A Socio-Rhetorical Commentary on the Epistle 'to the Hebrews' (Grand Rapids: Eerdmans, 2000): 20.

2 Kenneth L. Schenck, A New Perspective on Hebrews: Rethinking the Parting of the Ways (Lanham: Fortress Academic, 2019): 123, n. 56.

3 Thomas Aquinas, Commentary on the Letter of St Paul to the Hebrews, tr. Fabian O. Larcher, Latin/English Editon of the Works of St Thomas Aquinas (Green Bay: Aquinas Institute, 2018): 10.1 para. 482. Others who doubt the significance of Heb. 10:2 for the date include Harold W. Attridge, The Epistle to the Hebrews (Hermeneia; Minneapolis: Fortress, 1989): 272; Alan C. Mitchell, Hebrews (SP 13; Collegeville: Liturgical Press, 2007): 200. Cf. also John Owen, The Exposition of the Epistle to the Hebrews, with Preliminary Exercitations, vol. 6, ed. W. H. Goold (7 vols; The Works of John Owen 19; 
Schenck and Aquinas are right of course, but I do not think I am wrong. The debate is sharpened with the 2017 publication of The Greek New Testament produced at Tyndale House (THGNT). Over against almost all recent editions of the Greek NT, ${ }^{4}$ this edition punctuates Hebrews 10:2 as a statement rather than a question, giving the following reading of Heb. 10:1-2a (my translation).

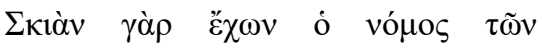

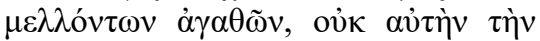

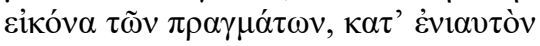

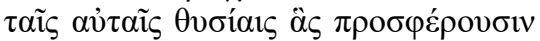

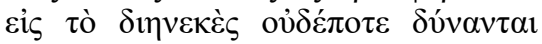

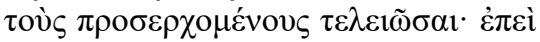

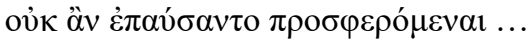

For since the law possesses a foreshadowing of the coming good things, not the actual manifestation of the realities, it cannot by the same sacrifices that are offered continually, year after year, make perfect those who approach. Otherwise they would not have ceased being offered ...

Punctuating Hebrews 10:2 as a statement rather than a question gives the clear impression that Hebrews was written after $70 \mathrm{CE}$, when the sacrifices had ceased. It reads as though the writer is giving a theological rationale for the fall of the temple in terms of the ineffectiveness of the sacrificial system. God has passed judgement on that system, and brought it to a decisive end.

In any version of the New Testament, punctuation is an interpretive decision since the major New Testament manuscripts have nothing (or very little) to indicate this. ${ }^{5}$ In what follows, I examine the punctuation of this verse as a statement from four perspectives to assess its validity. I will consider the manuscript evidence, the history of interpretation, questions of syntax, and the verse in its context. I will then briefly discuss rhetorical questions before returning to the question of the date of Hebrews.

Edinburgh: Johnstone \& Hunter, 1854): 432 - 'God would have appointed them to have been offered once, and no more.'

4 I say 'almost all'. Zane C. Hodges and Arthur L. Farstad, The Greek New Testament According to the Majority Text ( $2^{\text {nd }}$ edn; Nashville: Nelson, 1985) punctuate the verse as a statement. Arthur L. Farstad et al., The NKJV Greek-English Interlinear New Testament (Nashville: Nelson, 1994) has the Majority text in a column with an interlinear 'word-for-word English translation' as well as an 'idiomatic English translation' (p. vii). In the 'word-for-word' translation a question mark appears at the end of the verse and the 'idiomatic' translation reads as a question.

5 Discussion of punctuation seems rare in journal articles. One example of such a discussion (also arguing for questions rather than statements) is Chrys C. Caragounis, 'Romans 5. 15-16 in the Context of 5. 12-21: Contrast or Comparison', NTS 31 (1985): 142-48. I have checked several English versions of the verses discussed by Caragounis and note that only the $\left(1890,3^{\text {rd }}\right.$ edn) New Translation by J. N. Darby (first published in 1867 ) treats the opening clauses in Rom. 5:15 and 16 as rhetorical questions. 


\section{Manuscript Evidence}

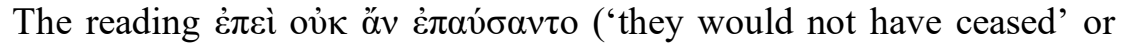
'would they not have ceased?') is the best attested. ${ }^{6}$ But there are two variant readings. The earliest extant Hebrews manuscript, $\mathrm{P}^{46}$, reads غ̇ $\pi \varepsilon \grave{~}$

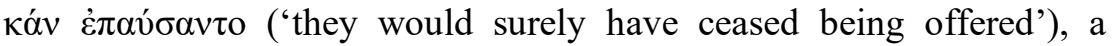
reading adopted by the NEB and the REB. A few late manuscripts (tenth to fourteenth centuries) omit the negative particle to give the reading $\dot{\varepsilon} \pi \varepsilon i$ $\not \alpha \nu \dot{\varepsilon} \pi \alpha v \sigma \alpha v \tau$, making sure that the sentence is a (positive) statement, 'they would have ceased being offered'. This reading was reflected in the Elzevir 1624 Textus Receptus, while Scrivener's Textus Receptus (1908) includes the negative particle ov̉к. ${ }^{7}$ The KJV reads the text as a question in the main text with a positive statement in a footnote, ${ }^{8}$ and the NKJV reads it as a question.

The reading غ̇ं $\varepsilon \dot{~ o ̈ ~} v$ probably arose to ensure that readers did not take the sentence as a (negative) statement rather than a question. ${ }^{9}$ Bruce

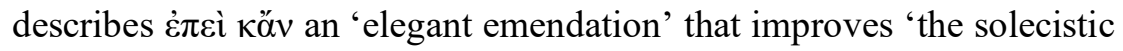

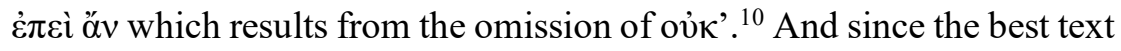
is the one that explains the genesis of other variants, ${ }^{11} \dot{\varepsilon} \pi \varepsilon i$ oủ $\alpha^{\prime \prime} v$ $\dot{\varepsilon} \pi \alpha v ́ \sigma \alpha v \tau$ ('they would not have ceased' or 'would they not have ceased?') should be adopted.

6 Paul Ellingworth, The Epistle to the Hebrews (NIGTC; Grand Rapids: Eerdmans, 1993): 494. It is supported by the three major Uncial MSS ( $\aleph$, A, C, and a host of other manuscripts as well as the Majority text). Note that Heb. 9:14-13:25 is missing from Codex Vaticanus.

7 The transmission history of the Textus Receptus is complex and beyond my scope. The various versions differ at Heb. 10:2. By 'Scrivener's Textus Receptus' I refer to The New Testament in Greek According to the Text Followed in The Authorised Version together with the Variations Adopted in The Revised Version, ed. F. H. A. Scrivener (Cambridge: CUP, 1908 [1881]).

8 I refer to the 1900 edition. See Goold's footnote in Owen, Hebrews, vol. 6, 431, n. 1, who notes that ' $[\mathrm{t}] \mathrm{his}$ passage is one in which the A.V. differs from the textus receptus'. 9 Attridge, Hebrews, 267, n. 6 suggests that this reading 'is probably a correction based on the failure to recognize the adversative sense of $\dot{\varepsilon} \pi \varepsilon$ and to construe the sentence as a rhetorical question'. See also Craig R. Koester, Hebrews: A New Translation with Introduction and Commentary (AB 36; New York: Doubleday, 2001): 431; this was also the opinion of Franz Delitzsch, Commentary on the Epistle to the Hebrews, tr. Thomas L. Kingsbury (vol. II; Edinburgh: T\&T Clark, 1870): 146. See also G. Zuntz, The Text of the Epistles: A Disquisition upon the Corpus Paulinum (The Schweich Lectures of the British Academy, 1946; London: OUP, 1953): 45-46.

10 Bruce, Hebrews, 234, n. 5.

11 A. K. M. Adam, 'De-coding Hermeneutics', HBT 41 (2019): 127-61, quote from p. 152. 


\section{The Weight of Tradition}

Every commentator I have consulted reads the text as an affirmation that were the sacrifices effective they would have ceased. I mention Chrysostom, ${ }^{12}$ Aquinas, ${ }^{13}$ Calvin, ${ }^{14}$ Owen,${ }^{15}$ Westcott,${ }^{16}$ Attridge,${ }^{17}$ and Cockerill. ${ }^{18}$ Oecumenius and Theophylact, whose provenance is uncertain and who often agree word for word, both state explicitly that it is to be read as a question. ${ }^{19}$ The same applies to English Bible translations from Wycliffe in the late fourteenth century through Tyndale's New Testament (1526), the KJV and NKJV, as well as the NRSV, the ESV, the 2011 NIV, and everything in between.

To be sure, some less formal translations like the GNB, CEV, and NLT eliminate the question in favour of a direct statement, with the GNB reading 'If the people worshipping God had really been purified from their sins, they would not feel guilty of sin any more, and all sacrifices would stop. ${ }^{20}$ But the intent is the same. All the translations either ask a

12 Homily 17 on Hebrews (see PG 63, 129-30, $N P N F^{l}$ 14:448). Chrysostom cites the

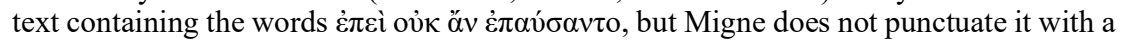
question mark. Later, Chrysostom says 'For if they were set free from all their sins, the sacrifices would not have gone on being offered every day' (Eỉ $\gamma \grave{\alpha} \rho \pi \alpha ́ v \tau \omega \nu \tilde{\eta} \sigma \alpha \nu$

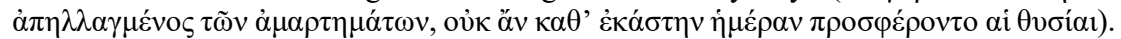
Reading the text as a statement would require him to say 'For if they were set free from all their sins, the sacrifices would not have stopped being offered.'

13 See the quotation above from Aquinas (p. 282).

14 Ioannis Calvini, 'Commentarius in Epistolam ad Hebraeos' in Joannis Calvini opera quae supersunt omnia, Volume 55, ed. Edouard Cunitz, Johann-Wilhelm Baum, and Eduard Wilhelm Eugen Reuss (Brunsvigae: Schwetschke, 1896): 121. English translation: John Calvin, Commentaries on the Epistle of Paul the Apostle to the Hebrews, tr. John Owen (Albany: Ages Software, 1996): 140 - 'When there is no longer any consciousness of sin, there is then no need of sacrifice; but under the Law the offering of the same sacrifice was often repeated; then no satisfaction was given to God, nor was guilt removed nor were consciences appeased; were it otherwise there would have been made an end of sacrificing [alioqui finis sacrificandi factus esset]'.

15 Owen, Hebrews, vol. 6, 431-34. Owen cites the TR, which omits the negative particle, but notes the textual variant, pointing out that if it is included 'the words are to be read as an interrogation' (p. 432).

16 Westcott, Hebrews, 308.

17 Attridge, Hebrews, 272.

18 Gareth Lee Cockerill, The Epistle to the Hebrews (NICNT; Grand Rapids: Eerdmans, 2012): 430.

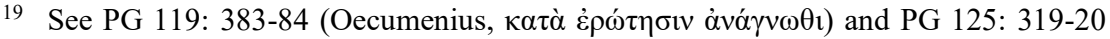

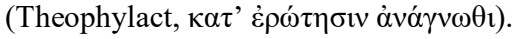

20 See the discussion in Paul Ellingworth and Eugene A. Nida, A Handbook on the Letter to the Hebrews (New York: United Bible Societies, 1983): 214, showing how the same semantic value can be applied to both a question and a statement. 
rhetorical question requiring a positive answer or state the answer to that question.

\section{Questions of Syntax}

As part of a brief discussion of the textual issues, Ellingworth states unequivocally that the reading that is best attested 'requires the sentence to be taken as a rhetorical question expecting the answer: "Yes, the sacrifices would have stopped." 21 This raises questions of syntax.

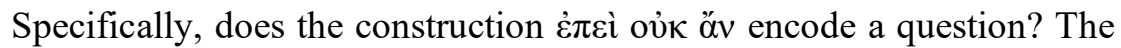
expression does not appear elsewhere in the Greek Bible, although oủ öv does. That construction with the aorist indicative (as here) appears eight times elsewhere in the NT, always as part of the apodosis of a conditional sentence. It is always a statement and never a question. ${ }^{22}$ The

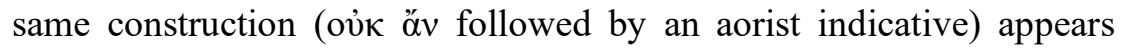
thirteen times in the LXX, again always in the apodosis of a conditional sentence, sometimes as a statement, ${ }^{23}$ and sometimes as a question. ${ }^{24}$

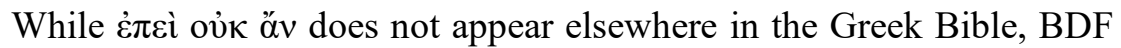
refers to an instance in the Greek papyri from 164 BCE..$^{25}$ Even there it

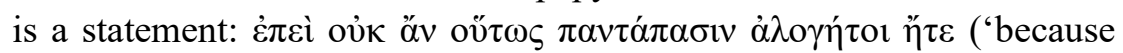
otherwise you would not be so unreasonable'). ${ }^{26}$

21 Ellingworth, Hebrews, 494.

22 See Matt. 12:7 ('you would not have condemned the innocent'); 24:22//Mark 13:20 ('Nobody would be saved'); Matt. 24:43//Luke 12:39 ('he would not have let his house have been broken into'); John 11:21,32 ('my brother would not have died'); 18:30 ('we would not have handed him over'); 1 Cor. 2:8 ('they would not have crucified the Lord of glory'). It also appears five times with the imperfect indicative, also as a statement. See Matt. 23:30 ('we would not have participated'); John 9:41 ('you would not be guilty of sin'); 1 Cor. 11:31 ('we would not be judged'); Gal. 1:10 ('I would not be a slave of Christ'); Heb. 4:8 ('he would not have spoken'); 8:4 ('he would not be a priest').

23 Judg. 8:19 ('I would not have killed you'); 13:23 ('he would not have taken ... he would not have shown ... he would not have made us hear'); 14:18 ('you would not have discovered my riddle'); Jdt. 11:12 ('I would not have taken up my spear'); 4 Macc. 2:20 ('he would not have spoken thus').

24 Obad. 5 ('would they not steal ... would they not leave?'); 4 Macc. 7:22 ('would not [that person] have control over emotions?'); 4 Macc. 17:7 ('would not those who are watching shudder?').

25 F. Blass, A. Debrunner, and R. W. Funk, A Greek Grammar of the New Testament and other Early Christian Literature (Chicago: University of Chicago Press, 1961): 182, para. 360 (2).

26 See Edwin Mayser, Grammatik der griechischen Papyri aus der Ptolemäerzeit, vol. II 1 (Berlin: de Gruyter, 1926): 228. 
The conjunction غ̇ $\pi \varepsilon \dot{~ a p p e a r s ~ t w e n t y-s i x ~ t i m e s ~ i n ~ t h e ~ N e w ~ T e s t a m e n t, ~}$ with a variety of senses. ${ }^{27}$ Nine of these occurrences are in Hebrews, more than any other New Testament book. Frequently throughout the New Testament it is simply a causal particle with the sense of 'because' or 'since'. ${ }^{28}$ Another use in the New Testament, appearing in Paul and in Hebrews, is in elliptical expressions with the sense (as here) 'for otherwise' or 'for if it were different'. ${ }^{29}$ In some of these cases (Rom.

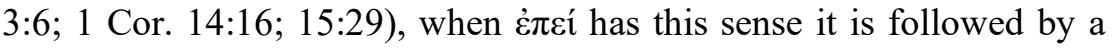
rhetorical question, although there the question is encoded using interrogative particles such as $\pi \tilde{\omega} \varsigma$ ('how?') and $\tau i$ ('what?').

This construction may also appear in Hebrews 9:17, where Delitzsch suggests that the clause following غ̇ $\pi \varepsilon$ í may be read as an interrogative, ${ }^{30}$ as also Westcott, who wonders if it 'best suits the rhetorical form of the passage'. ${ }^{31}$ Bruce is more adamant, translating 'A testament is valid only

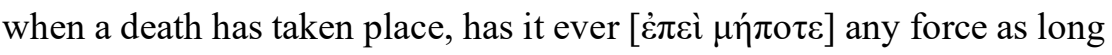
as the testator stays alive?' He notes that treating it as a question 'does best justice to the negative $\mu$ ', which is appropriate in a question expecting the answer "No". ${ }^{32}$ And BDF claims that that the clause is 'clearly interrogative'. ${ }^{33}$ If this is correct (although I am unaware of any translation that reads the verse in this way), it does show the writer of Hebrews using غ̇ $\pi \varepsilon \dot{~ i n ~ a n ~ e l l i p t i c a l ~ s e n s e, ~ f o l l o w e d ~ b y ~ a ~ r h e t o r i c a l ~}$ question, this time expecting the answer 'no'. So while غ̇ं $\varepsilon i$ in elliptical clauses does not demand a question, it is sometimes followed by a rhetorical question, and the writer uses the construction in this way in Hebrews 9:17.34

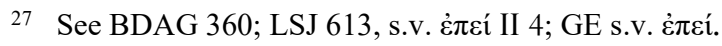

28 Matt. 18:32; 21:46; 27:6; Mark 15:42; Luke 1:34; John 13:29; 19:3; 1 Cor. 14:12; 2 Cor. 11:18; 13:3; Heb. 2:14; 4:6; 5:2,11; 6:13; 9:17; 11:11.

29 Rom. 3:6; 11:6,22; 1 Cor. 7:14; 14:16; 15:29; Heb. 9:26; 10:2.

30 Delitzsch, Hebrews, vol. II, 107-108, 146.

31 Westcott, Hebrews, 268.

32 Bruce, Hebrews, 219, n. 104. See also the comments in James A. Moffatt, A Critical and Exegetical Commentary on the Epistle to the Hebrews (Edinburgh: T\&T Clark, 1924): 128; William L. Lane, Hebrews 9-13 (WBC 47B; Dallas: Word, 1991): 229 n. u (who disagrees).

33 BDF 428 (5).

34 In this discussion of syntax I leave aside the tense of the verb $\pi \rho \circ \sigma \varphi \varepsilon \dot{\varepsilon} \omega$ in the clause

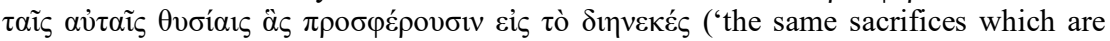
continually offered') in v. 1. Although, had the temple already fallen and sacrificial activity ceased, it might have been more natural for the author to use the imperfect tense. This is, however, not decisive. See the brief discussion of the significance of the use of present tense verbs in this part of Hebrews in Philip Church, 'The Temple in the 


\section{Hebrews 10:2 in the Context of 10:1-18}

Hebrews 10:1-18 brings the long central section to a conclusion with four paragraphs, each concluding with a categorical declaration. Verses 1-4 conclude that the blood of bulls and goats cannot remove sin (v. 4); verses 5-10 claim that Christ's offering of himself has abolished the former sacrifices; verses 11-14 conclude with the claim that Christ, by his single sacrifice, has perfected forever the sanctified ones (v. 14); and verses 15-18 cite parts of Jeremiah 31:33-34 and conclude that the claim of Jeremiah, that God will no longer remember the sins of the people, means that forgiveness has been achieved. Consequently, there is no further need for sacrificial offerings (v. 18). The section is about the inability of the sacrifices of the former covenant to achieve forgiveness, and the present availability of forgiveness for the people of God by Christ's unique offering of himself. ${ }^{35}$

These four paragraphs compare the animal sacrifices offered repeatedly under the law by priests who stand each day performing their rituals with the single, once-and-for-all self-offering of Jesus Christ, who, having made this offering, sat down, having achieved forgiveness of sins for all time. The writer argues that the single sacrifice of Christ has rendered the animal sacrifices offered under the law unnecessary by marshalling arguments from Scripture, and by setting out propositions and drawing logical conclusions from them. Verses 1-4 fit into this pericope as part of the claim that the former sacrifices are ineffective. It may be paraphrased as follows, first with verse $2 \mathrm{a}$ as a statement and then as a rhetorical question demanding the answer 'yes'.

For the law cannot make those who approach perfect by the same sacrifices that are continually offered each year.

Otherwise, they would not have ceased to be offered, because the worshippers having been cleansed once and for all would no longer have any awareness of sins.
Otherwise, would they not have ceased to be offered, because the worshippers having been cleansed once and for all would no longer have any awareness of sins?

Actually, in these sacrifices there is an annual reminder of sins, for the blood of bulls and goats cannot take away sins.

Apocalypse of Weeks and in Hebrews', TynBul 64 (2013): 109-28, esp. 115-17, and the bibliography cited there.

35 This paragraph is taken from Church, Hebrews and the Temple, 428, slightly modified. 
Westfall analyses the flow of the discourse in verses 1-4 like this:

The rhetorical question in v. 2 elaborates the central clause of v. 1, restating that the sacrifices were unable to perfect the ones drawing near to God. The next sentence in $\mathrm{v}$. 3 elaborates the rhetorical question with a positive restatement. ${ }^{36}$

This highlights the problem with reading the clause as a statement. If it is read in this way, there are three contradictory reasons for the end of the sacrificial system: (1) they are ineffective - they cannot make those who approach perfect; (2) they are effective - the worshippers have been cleansed once and for all and no longer have an awareness of sin; and (3) they are ineffective and all they do is perpetuate the guilt. ${ }^{37}$ As Zunst pointed out eighty years ago, if the clause is read as a statement, it contradicts the context, ${ }^{38}$ not only of verses $1-4$, but of the entire pericope. Either these sacrifices are ineffective (vv. 1b, 3) or they are effective (v. 2b). They cannot be both effective and ineffective at the same time.

When read as a question, however, the argument is clear. The writer is thinking about the effectiveness or otherwise of the Old Testament sacrificial system. He is clear that the sacrifices are ineffective and he states it three times to drive his point home, twice with a statement and once with a rhetorical question: (1) the sacrifices are ineffective - they cannot make perfect those who approach; (2) if they were effective, then the worshippers would have been cleansed once and for all and no longer have an awareness of $\sin$ - why, then, would there be any need for further sacrificial activity?; and (3) they simply serve as an annual reminder of sin, perpetuating the guilt.

Thus, I argue that the sentence should be read as a rhetorical question expecting the answer 'yes'. If the sacrifices were effective, they would have ceased being offered.

\section{Rhetorical Questions}

Rhetorical questions seem to have been a favourite device of the writer of Hebrews. There are eighteen of them. Of these, two are quotations

36 Cf. Cynthia Long Westfall, A Discourse Analysis of the Letter to the Hebrews: The Relationship between Form and Meaning (LNTS 297; London: T\&T Clark, 2005): 220.

37 Westfall, Discourse Analysis, 220.

38 Zuntz, Text, 46. 
from the Jewish Greek Scriptures, ${ }^{39}$ and for five of them he supplies the answer. ${ }^{40}$ There are two qal wehomer (how much more) questions ${ }^{41}$ and three 'to whom' questions. ${ }^{42}$ One question refers to his own discourse, when he asks 'what more can I say' (11:32). Of the remainder, ${ }^{43}$ two require the answer 'yes', ${ }^{44}$ one of which is Hebrews 10:2, as discussed here: 'Otherwise, would not the former sacrifices have ceased being offered, since the worshippers, cleansed once for all, would no longer have any consciousness of sin?'

In every case the answer to the question is obvious (which is the nature of a rhetorical question). As Randolph Quirk writes, for a rhetorical question 'the answer is a foregone conclusion ... it essentially seeks confirmation of what the speaker has explicitly assumed'. ${ }^{45}$ Thus, while a rhetorical question might be 'interrogative in structure ... [it] has the force of a strong assertion', ${ }^{46}$ says Quirk. Therefore the GNB is technically correct to translate Hebrews 10:2 as it has: 'If the people worshipping God had really been purified from their sins, they would not feel guilty of sin any more, and all sacrifices would stop.'

Unfortunately, when the GNB does this, it flattens out the rhetoric. As Leland Ryken maintains, '[t]he purpose [of a rhetorical question] is to move a reader or listener to assent, "Yes, this is in fact true." 47 The writer uses such a question as part of his rhetorical strategy of "evoking the listener to ponder the implications of what was said'. ${ }^{48}$ In this case, the writer wants the reader to ponder the question and affirm 'Yes, indeed, the sacrifices would have ceased.'

\footnotetext{
39 Heb. 2:6 (Ps. 2:6); 13:6 (Ps. 118:6).

40 There are five questions in Heb. 3:16-18, all of which have the answer stated in 3:18: the disobedient wilderness generation.

41 Heb. 2:2-4; 10:29.

42 Heb. 1:5,13.

43 Heb. 1:14; 7:11; 10:2; 12:7,9.

44 Heb. 1:14; 10:2.

45 Randolph Quirk et al., A Comprehensive Grammar of the English Language (London: Longman, 1985): 1478.

46 Quirk et al., Comprehensive Grammar, 825. Cf. Adina Moshavi, 'What Can I Say? Implications and Communicative Functions of Rhetorical "WH" Questions in Classical Biblical Hebrew Prose', VT 64 (2014): 93-108, '[t]he rhetorical question is a question used to indirectly express an assertion' (p. 94).

47 Leland Ryken, Short Sentences Long Remembered: A Guided Study of Proverbs and other Wisdom Literature (Reading the Bible as Literature; Bellingham: Lexham, 2016): 109.

48 Richard A. Young, Intermediate New Testament Greek: A Linguistic and Exegetical Approach (Nashville: Broadman \& Holman, 1994): 221.
} 


\section{Implications for the Date of Hebrews}

The logic of Hebrews 10:1-4, and indeed the entire section from 10:118 , contrasting the one, unrepeatable, and unrepeated sacrifice of Jesus with the endless repetition of the Day of Atonement ritual over the centuries, requires the rhetorical question in verse 2a: were these sacrifices effective, would they not have ceased (and as Schenck and others would add, ceased long ago)? Schenck and others are not wrong. The sacrifices would have ceased long ago. But there is another consideration. The point of the rhetorical question is to make the readers think, and to supply the answer. Had the writer told them that the sacrifices would cease if they were effective (like the Good News Bible does), they may have just kept reading and overlooked the implications of his statement. But if they had to pause and supply the answer, this is quite a different matter. If the temple had fallen and the sacrifices had ceased the answer might be (in the words of F. F. Bruce) 'Well, they have ceased to be offered.' Bruce continues, 'a superficial objection, no doubt, but even so one to which such a skilled disputant is unlikely to have laid himself open'. ${ }^{49}$

It seems to me that Bruce (and others who look to this verse to posit an early date for Hebrews) are right. The structure of this rhetorical question requires the answer 'yes'. Had the temple been destroyed and the sacrifices ceased, the readers would simply be confused, thinking, 'But they have ceased to be offered.' Was the temple still standing and were the sacrifices still being offered, would not the readers walk away pondering the point of all this ongoing sacrificial activity? For that seems to have been the fundamental reason for the letter in the first place. ${ }^{50} \mathrm{~A}$ group of ethnic Jewish believers in Rome was attracted to the worship of the temple in Jerusalem, and were maybe attending celebratory synagogue meals centred on the temple. ${ }^{51}$ The writer was convinced that if they went down that road, there was no return. A rhetorical question at this point was an effective way to get them to see that the sacrificial activity going on in the temple was no longer effective. They needed to put the sacrifices of the temple and the temple itself behind them and

49 Bruce, Hebrews, 236, n. 12. Bruce's entire note says ' $[\mathrm{h}]$ ad he been writing after AD 70 and had he worded his argument precisely in these terms, it could have been said: "Well, they have ceased to be offered.",

50 See e.g. Church, Hebrews and the Temple, 358-67.

51 See Barnabas Lindars, 'The Rhetorical Structure of Hebrews' NTS 35 (1989): 382406, esp. 388. 
look to the once-and-for-all self-offering of Jesus, through which they had been sanctified (Heb. 10:10).

This article argues for an early date for Hebrews based on a rhetorical question in 10:2. The witnesses to the text indicate that the most likely

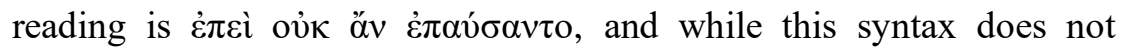
specifically encode a question, it permits one. The flow of the discourse requires the clause to be read as an elliptical clause followed by a rhetorical question. And since that is the case, the verse points to an early date for Hebrews, before sacrificial activity in the temple had ceased.

\section{Postscript}

I have no illusions as to the complexity of producing a new edition of the Greek New Testament and the enormity of the task. The editor and associate editors are to be honoured for producing such an elegant edition. I suspect that the decision to punctuate the verse in this way was inadvertent rather than a conscious decision. In a personal communication dated 14 January 2020 , the editor writes, '[i]t is probably

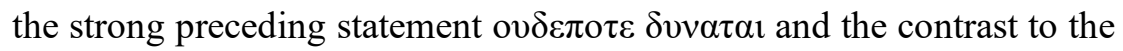
$\varepsilon \pi \varepsilon 1$ оvк $\alpha v$, with $\alpha v$ indicating the irrealis, that would evoke the question in a good reader ... I have made the change in the file for the next edition. $^{\text {52 }}$

${ }^{52}$ Personal e-mail to the author from Dirk Jongkind dated 14 January. Cf. Attridge, Hebrews, 267, n. 6. 